\title{
BOUNDARIES: AN INTERDISCIPLINARY (HI)STORY
}

Author:

D. S. Strauss ${ }^{1}$

\section{Affiliation:}

${ }^{1}$ School of Philosophy, NorthWest University, Potchefstroom Campus

\section{Correspondence to:}

Danie Strauss

\section{Postal Address:}

Private Bag X6001,

Potchefstroom Campus, NorthWest University, Potchefstroom, 2520, South Africa

Email:

dfms@cknet.co.za

Dates:

31 Oct 2016

How to cite this article: Strauss, D.F.M., 2016.

"Boundaries: an Interdisciplinary (Hi)Story". KOERS - Bulletin for Christian Scholarship, 81(2). Available at: https://doi.org/10.19108/ KOERS.81.2.2273

\section{Copyright:}

(C) 2016. The Author(s).

Published under the Creative Commons Atribution License.
The experience and awareness of boundaries forms an integral part of being human. This article investigates the systematic philosophical underpinnings of our understanding of the nature of boundaries, in some instances supported by historical considerations. It stands to reason that boundaries are related to our awareness of spatial relationships, even though this awareness cannot avoid incorporating the distinction between entities and properties, reflected in the distinction between the concrete what and the how of reality. Differences between the original (mathematical) meaning of space and other contexts within which we encounter analogies of spatial boundaries are considered by paying attention to the problem of accounting for physical space (which is neither continuous nor infinitely divisible), biotic and sensory space (compare notions such as Umwelt, ambient and environment) as well as the significance of closed and open systems also for inter-human relationships displaying a solidary unitary character, analogous to thermodynamic open systems. Boundaries between different modes of explanation finally underscore the typical on-going task of philosophy, namely to investigate boundary questions. It will be argued that the problem of the multivocal nature of the term boundary only finds a satisfactory solution if it is embedded in a non-reductionist ontology.

Key concepts: boundaries, analogical contexts, irreducibility, uniqueness (primitive terms), nonreductionist ontology

Die ervaring van grense vorm ' $\mathrm{n}$ integrale deel van menswees. Hierdie artikel ondersoek die sistematies-wysgerige onderbou van ons verstaan van die aard van grense. In sommige gevalle word hierdie ondersoek ondersteun deur oorwegings uit die geskiedenis van die filosofie en die vakwetenskappe. Dit spreek vanself dat grense verband hou met ons besef van ruimteverhoudinge, selfs al kan hierdie besef nie ontkom aan die onderskeiding tussen entiteite en hul eienskappe, soos wat dit gereflekteer word in die onderskeid tussen die konkrete wat en die hoe van die werklikheid nie. Verskille tussen die oorspronklike (wiskundige) sin van ruimte en ander kontekste waarin analogieë van die aard van ruimtelike grense ter sprake kom, word in oënskou geneem deur die probleem aan die orde te stel van hoe ons rekenskap moet gee byvoorbeeld van fisieke ruimte (wat nie kontinu en oneindig verdeelbaar is nie), biotiese en sensitiewe ruimte (bedink terme oos Umwelt, "ambient" en omgewing), asook die betekenis van geslote en oop sisteme, ook vir die aard van inter-menslike relasies wat oor 'n solidêre eenheidskarakter beskik, analoog aan termodinamiese oop sisteme. Die grense tussen verskillende verklaringsmodi belig die voortgaande taak van die filosofie om rekenskap van grensvrae te gee. Die argument wat gevoer word loop uit op die gevolgtrekking dat die probleem van 'n meersinnige gebruik van terme soos grense slegs tot ' $n$ bevredigende oplossing gebring kan word indien hierdie probleem in ' $n$ niereduksionistiese ontologie ingebed word.

Kernbegrippe: grense, analogiese kontekste, onherleibaarheid, uniekheid (primitiewe terme), niereduksionistiese ontologie 
The key issue investigated in this article concerns the question how our richly varied awareness of boundaries could be related to a shared basic problem. It is argued that the notion of a "boundary" is indeed embedded in widely differing contexts, which raises the question whether these contexts are related in a univocal or multivocal way. If the term "boundary," as it appears in different contexts, does not have the "same meaning", then the challenge will be to investigate its multivocality and find a theoretical explanation for this phenomenon. Another way to formulate the problem is: are there similarities and differences attached to the term boundary as it is employed in different contexts and if so, how do we have to account for such differences and similarities? Intimately related to this issue is the problem regarding different modes of explanation. Are such modes of explanation unique and irreducible? If the answer is affirmative, then the term "boundary" inevitably will display an inherent ambiguity or multivocality. Searching for an answer to these problems will have to account for the coherence between what is unique and irreducible. Yourgrau explains this problem with reference to Gödel who "insisted that to know the primitive concepts, one must not only understand their relationships to the other primitives but must grasp them on their own, by a kind of 'intuition' " (Yourgrau 2005:169). Perhaps the most basic question is whether these problems could be resolved by means of a non-reductionist ontology.

\section{LIFE-WORLD}

From our early childhood onwards we encounter borders. The inside and outside of a house, the inside and outside of the yard, and eventually, in geography classes at school, we learn more about municipalities, districts, provinces, states, that is to say about the outside world.

This growing awareness is implicitly accompanied by the boundaries between different academic disciplines, including the natural sciences and the humanities. These disciplinary boundaries in turn reflect the boundaries demarcating the phenomena of everyday experience. If there are no boundaries between the various special sciences as well as "objective" reality, the universe will collapse into an amorphous nothingness, while all the academic disciplines will come together in an unidentifiable heap of chaos, for without boundaries it would be impossible to identify and distinguish. To identify something requires the presence of something that can be delineated, i.e., defined. Since analysis always at once entails an act of identification (concept formation) and an act of distinguishing, we first look at the relationship between analysis and boundaries.

\section{ANALYSIS AND BOUNDARIES}

To be sure, understanding reality requires the human ability to demarcate, that is, to think and conceptualize. Concepts in turn are intimately connected to a delimitation of those properties falling within and outside its boundaries. Defining something inevitably therefore has to specify what is demarcated and what not. This applies both to the acquisition of non-theoretical and theoretical concepts. In everyday life identifying and distinguishing things and events serve as a necessary condition for living an orientated life. Without the presence of this ability our life orientation will disintegrate. At the same time our sense of history and the science of history will collapse. Since language also depends upon the logical-analytical ability to identify and distinguish, the absence of boundaries will eliminate the foundation of (scientific) communication.

A related problem is whether or not there is an "original" meaning that can be attached to the term boundary?

\section{THE SPATIAL NATURE OF A BOUNDARY}

Sooner or later the question arises: What is the nature of a boundary? Obviously our first intuition should relate this question to our awareness of space. Is our awareness of what is inside and outside not dependent upon the spatial reality of a closed surface, such as a circle, a plane or a cube?

But what kind of space do we have in mind? Is it physical space? If so, are there other kinds of space? Is there a difference between Euclidean (or non-Euclidean) space on the one hand and physical space on the other? May we say, on a more general level, that mathematical space differs from physical space? And what about the bio-milieu of living entities, their Umwelt is it a kind of biotic space? Moreover, why are we aware of still other kinds of space, such as emotional space, logical space, cultural space, semantic domains or social space?

In order to find an answer to these questions another distinction ought to be considered first of all.

\section{ENTITIES AND PROPERTIES}

Perhaps these questions may be related to a different distinction, namely that between what is concrete and what is abstract. For example, is physical space "concrete" and mathematical space "abstract"? This question suggests that there is a difference between the concrete "what" (thingness) of reality and the "how," the different ways, modes or aspects within which all things function. Although the distinction between what and how is sound, it may convey the mistaken impression that the various aspects of reality, as modes of being are not real, that they do not have an ontic status. Are they not merely modes of thought, as Descartes asserted by stating that number and all universals are nothing but modes of thought (Principles of Philosophy, Part I, LVII)? We may even go further back and consider the views of Aristotle. His understanding relates to the problem of discreteness and continuity.

\section{FROM ARISTOTLE TO MATHEMATICS AS GEOMETRY}

Aristotle holds that "quantity is either discrete, or continuous" (Categoriae, 4 b 20). He continues with the assertion that "[n] umber, ... is a discrete quantity" (Cat., 4 b 31), which means that a discrete quantity does not have a common limit or boundary. However, in the case of a line as a continuous quantity, it does have common limits or boundaries among its parts (see Cat., 4b 25ff., 5 a 1ff.). This entails that continuity displays 
an endless divisibility: "everything continuous is divisible into divisibles that are infinitely divisible" (Phys., 231 b 15-17; Aristotle 2001:317).

Unfortunately introducing quantity as a genus concept [genus proximum], with discreteness and continuity as embodying specific differences [differentia specifica], denies the uniqueness and irreducibility of number and space. Nonetheless, Greek philosophy and mathematics have set the scene, witnessing an on-going attempt either to reduce space to number or number to space. With the discovery of irrational (so-called incommensurable) numbers, the initial Pythagorean thesis that everything is number gave way to a geometrization of mathematics, a perspective dominating the scene until the end of the $19^{\text {th }}$ century when Weierstrass, Cantor and Dedekind believed having accomplished a new arithmetization of mathematics. However, early in the $20^{\text {th }}$ century Frege once more reverted to the view that mathematics actually is geometry. ${ }^{1}$

\section{THE CONTINUUM: SMOOTH INFINITESIMAL ANALYSIS}

At the beginning of the $21^{\text {st }}$ century the French mathematician Longo remarks that for Thom and many other "mathematicians of the continuum" the continuum ontologically precedes the discrete. The latter, discreteness, has to be appreciated negatively as "a broken line" (Longo 2001:6) or even a catastrophe (Longo 2001:19). And more recently, in the development of "smooth infinitesimal analysis" (SAI), the impossibility of reducing continuity to discreteness is categorically affirmed by Bell: "Smooth infinitesimal analysis provides an image of the world in which the continuous is an autonomous notion, not explicable in terms of the discrete" (Bell 2006:284). Note that the idea of "an autonomous notion" is equivalent to what Gödel had in mind with his idea of "primitives" - mentioned earlier.

Modern mathematics continues to reflect on this relation between discreteness and continuity. In a twofold sense it relates to the problem of what a boundary is: (i) what is discrete appears to lack a common boundary and (ii) if continuity cannot be arithmetized there is an unbridgeable boundary between the aspects of number and space. These remarks need to be elucidated in some more detail.

\section{DISCRETENESS: THE LACK OF A COMMON BOUNDARY}

Merely looking at number and space already reveals more than one instance of the notion of a boundary. Since numbers are distinct, discreteness applies to all kinds of numbers. Two distinct numbers never have a shared boundary. Paul Bernays, the co-worker of David Hilbert, also accepts discreteness and continuity in their irreducibility and as a result he questions the idea that mathematics could be completely arithmetized:

\footnotetext{
1 "The more I have thought the matter over, the more convinced I have become that arithmetic and geometry have developed on the same basis - a geometrical one in fact - so that mathematics in its entirety is really geometry" (Frege 1979: 277).
}

"We have to concede that the classical foundation of the theory of real numbers by Cantor and Dedekind does not constitute a complete arithmetization of mathematics. It is anyway very doubtful whether a complete arithmetization of the idea of the continuum could be fully justified. The idea of the continuum is after all originally a geometric idea" (Bernays 1976:187-188).

In his Introduction to Infinitesimal Mathematics, Laugwitz states that from the outset Cantor's set concept is constructed in such a way that what is continuous withdraws itself from its grip. According to Cantor a set unites (in the sense of bringing together - "Zusammenfassung") properly distinct objects ("wohlunterschiedener Dinge") into a whole (see Cantor 1895:481). From this Laugwitz concludes: "the discrete reigns" ("das Diskrete herrscht" - Laugwitz 1986:10). What is truly discrete does not have common boundaries - as asserted by Aristotle.

The original spatial meaning of continuity immediately differentiates into multiple dimensions of spatial extension and these distinct dimensions are correlated with distinct magnitudes. How does this insight then contribute to an understanding of boundaries?

\section{DIMENSIONS AND MAGNITUDES}

From a spatial perspective both multiple dimensions and various magnitudes are expressed by using numbers. The infinite divisibility of spatial continuity, as noted already, and appreciated by Aristotle, represents one feature of continuity. That every point of division is taken twice provides the other criterion, also already recognized by Aristotle. Böhme shows that Cantor's definition of the continuum contains two elements met by the Aristotelian definition: coherence and dividing points for infinite division (Böhme 1966:309). While only allowing a Dedekind-cut at divisions, Böhme substantiates his argument as follows:

when a Cantorian continuum as such is divided into two by means of the indication of a point so that the one set contains those points which are in numerical value greater than or equal to the indicated point, while the other set contains those points of which the numerical value are smaller than or equal to the numerical value of the indicated point, both parts are again continuous. Such divisions are possible into infinity (due to the perfection of the continuum), and the parts are still coherent in the Aristotelian sense (i.e. their limit-points [boundaries] are the same) (Böhme 1966:309).

At this point an additional perspective is needed in order to comprehend how the notion of a boundary actually entails what presently shall be designated as the spatial subject-object relation. 


\section{BOUNDARIES: THE SPATIAL SUBJECT- OBJECT RELATION}

Aristotle employs the notion of a boundary (or limit) also in his theory of abstraction, reminiscent of spatial notions. Later on Thomas Aquinas articulated a similar view while accounting for a one-dimensional line in terms of successive abstractions. A line-stretch is delimited by points as its extremities ("cuius extremitates sunt duo puncta" - Summa Theologica, I,85,8).

The one-dimensional extension of a line-stretch is delimited by its one-dimensional boundaries, its starting point and end point. Within one dimension points are spatial objects because they are not extended in one dimension. Lines, as one-dimensional subjects, may play a similar limiting (boundary) role in two dimensions, for example when three straight lines delimit a triangle, which is a spatial subject in two dimensions. Likewise a multiple number of two-dimensional subjects, such as surfaces, can serve as the boundaries of a cube as a threedimensional spatial subject. A spatial subject in $n$ dimensions can therefore be a spatial object in $n+1$ dimensions. As a spatial object in one dimension a spatial point is a subject in zero dimensions. In terms of the fundamental difference between a spatial subject and a spatial object, it is impossible to deduce spatial extension from spatial objects (points).

Continuous dimensional extension highlights the core (primitive) meaning of space, its irreducibility, while at the same time it reveals the coherence between space and number: there are 1, 2, 3 or more dimensions (let us call this a numerical analogy within the aspect of space) while magnitudes are also expressed in specifying numbers (such as three feet, ten square miles, and so on).

The next problem concerns the question if other aspects, different from space, in their uniqueness also cohere with space - and if so, whether this phenomenon also depends upon similarities and differences? We first look at similarities and differences between the physical and spatial aspects.

\section{DOES NATURE MAKE JUMPS? MATHEMATICAL SPACE AND PHYSICAL SPACE}

Within a spatial context a boundary depends upon the spatial subject-object relation. Almost a hundred years ago Hermann Weyl objected to the set theoretical attempt to reduce the "continuum" to isolated points. He writes: "In order to present the continuous coherence of the points, contemporary analysis, because it has broken apart the continuum into isolated points, had to take recourse to the concept of an environment" (Weyl 1921:77).

Since Leibniz introduced his idea of the law of continuity (lex continui), wedded to the belief that nature does not make jumps (natura non facit saltus), natural scientists have been convinced that physical space is both continuous and infinitely divisible. However, in his commemorative article on Weierstrass which appeared in 1925 in Mathematische Annalen, Hilbert points out that physical space is neither continuous (by being bound to energy quanta) nor infinitely divisible (Hilbert 1925:164). Both mathematical space and physical space are extended, highlighting what is similar between them. Yet within this similarity the difference between mathematical space and physical space evinces itself, for whereas mathematical space is continuous and infinitely divisible, physical space is neither continuous nor infinitely divisible. ${ }^{2}$ Within the moment of similarity (being extended), the difference shows itself - in being and not being continuous and infinitely divisible. This is precisely what an analogy is all about. When two entities or aspects are similar in that respect in which they differ (and vice versa), we meet a genuine analogy. In the configuration of physical space we therefore discern a mathematical analogy within the physical aspect. ${ }^{3}$

One may also consider in what sense physics treats closed and open systems, because it enables one to see an "open border."

\section{PHYSICS: THE THERMODYNAMICS OF CLOSED SYSTEMS}

The first main law of modern physics, the law of the conservation of energy, states that since energy cannot be created or destroyed, over time the total energy of an isolated system remains constant. Perhaps a more precise formulation is found in designating it as the law of energy-constancy.

The second main law of thermodynamics, the law of nondecreasing entropy, was initially formulated for closed systems only. Within biology the problem of increasing order (decreasing entropy) appeared to be incompatible with the second law. The neo-vitalistic biologist, Hans Driesch, introduced an immaterial vital force, also designated as entelechie or psychoide, in order to solve this problem. He continues the deterministic conception of causality and aims at applying it to biotic phenomena as well.

\section{THE VITALIST ATTEMPT TO INTRODUCE AN IMMATERIAL VITAL FORCE}

A hundred years ago the neo-vitalism of Driesch dominated the scene on the basis of experimental research done on regeneration phenomena. It was discovered that at an early stage of development some animals are capable of regenerating an entire living entity from a small part of it. In the case of certain animals a part as tiny as $1 / 280^{\text {th }}$ can regenerate an entire animal. When a sea urchin with four cells is divided every single cell is capable of regenerating an entire mature sea urchin. This

$\overline{2}$ Bernays has a clear understanding of this difference between physical space and mathematical space: "Only through the contemporary development of geometry and physics did it become necessary to distinguish between space as something physical and space as an ideal multiplicity determined by spatial laws" (Bernays 1976:37, note 5).

3 Maddy addresses this issue as follows: "But it is also true that the appearance of, say, a continuous manifold in our best description of space-time does not seem to be regarded as establishing the continuity of space-time; the microstructure of spacetime remains an open question" (Maddy, 2005:455). 
suggests that every part has an equal potential to regenerate the whole organism, but if these parts are not separated they will not develop their full potential. Driesch holds that the vital force is responsible for harmonizing the potential of all the parts. As a result Driesch views living entities as "equi-potential harmonious systems."

According to him the vital force (entelechie) operates as a "totality-causal factor" (Ganzheitskausalität). He appreciates entelechie as a "system of negations" (Driesch 1921:513; 459 ff.), for it is non-mechanical, not energy, not force, not a constant (Driesch 1921:460) and non-spatial (Driesch 1921:513).

Yet it appears as if growth processes violate the law of nondecreasing entropy, for we note that according to this law within a closed system what is most probable would be an increase in disorder (the opposite of increasing complexity accompanying growth). This prompted Von Betalanffy to introduce a different understanding of borders by distinguishing what is "closed" and what is "open".

\section{VON BERTALANFFY: INTRODUCING OPEN SYSTEMS}

Ludwig von Bertalanffy soon expanded the second main law of thermodynamics (the law of non-decreasing entropy) to open systems, that is, to systems constantly in interaction with their environments. Non-living material processes, such as a glacier, a fire or an idling vehicle, are physical systems without fixed boundaries, because they are thermodynamically open. Although living entities are guided by their characteristic biotic function, they also have a function within the physical aspect of reality.

Karl Trincher distinguishes four macroscopic properties of the cell:

(a) spatial macroscopy, defining the boundaries of the cell through a spatially delimited surface; (b) temporal macroscopy, determining a finite time duration within which the energy cycle of the cell takes place a continuous process of assimilation and dissimilation of building material; (c) the isothermal nature of the cell manifested in maintaining the same temperature throughout the cell; and

(d) the enduring positive difference between the internal temperature of the cell and the external temperature of the environment adjacent to the cell surface, where the former is higher than the latter (Trincher 1985:336).

It is therefore clear that living things do not violate the law of non-decreasing entropy because the increasing order within such living entities is still less than the order extracted from the outside. Schrödinger calls this negentropy (negative entropy - Schrödinger 1955:71 ff.). Negentropy creates more disorder outside the living entity than the order built up inside it, thus illustrating the idea of an open border which is peculiar to thermodynamically open systems.
These developments caused neo-vitalist biologists to alter their arguments.

\section{AN "INSTABILITY FACTOR" AND POSITIONALITY: SCHUBERT- SOLDERN AND PLESSNER}

The approach of Driesch is continued by Rainer SchubertSoldern who formulates further biochemical arguments in support of his neo-vitalist position. It is remarkable that from a physical perspective a living entity prevails in a state of high statistical improbability, flowing from the fact that from a thermodynamic perspective it is an open system. It forms an unavoidable condition for the biotic health of living things, ensuring the biotic stability of such entities (a healthy state). The crucial point is that biotic stability requires and presupposes physical instability. At the same time physical stability (equilibrium) implies biotic instability (a sign that death is imminent). The neo-vitalist biologists who succeeded Hans Driesch, in particular Schubert-Soldern, introduced the phrase "instability factor" as a substitute for Hans Driesch's entelechie (cf. Schubert-Soldern 1959:62, 68; 1962:102 ff.). Heitler calls this instability factor a central instance directing the eventual teleological activities of living things. This "biologischen Instanz" (biological instance) also specifies the following subinstances (Unter-Instanzen), namely organs, cells, organelles (Heitler 1976:16).

Helmut Plessner notes the crucial difference between physical things and living entities in respect of boundaries. His aim is to transcend what he considers a self-contradictory notion, namely the idea of an "entelechie," passed on to him by Hans Driesch. His alternative is the notion of positionality. According to him the surrounding environment of physical entities serves as their delimiting boundary. However, when living entities are at stake this delimitation (boundary) is inherent to the entity itself, for example the membrane of a cell. This constitutes what Plessner calls positionality (Plessner 1975:291). More recently Trincher remarks that having a geometrically defined surface applies to macroscopic structures only, since even the largest macro-molecules are not delimited by a surface (see Trincher, 1985:336).

The account found in the thought of Schubert-Soldern underscores the same point in different terms. According to him the functional and formal unit of life, the cell, depends on the actualization of a twofold potential: "(a) the 'form' or order of the cell, and (b) the chemical laws governing molecules." He calls this "principle of order the 'active potentiality' of the material parts" (Schubert-Soldern 1962:102). This view goes back to Aristotle: "Hence the Aristotelian concept of entelechy corresponds exactly with the principle of order, which we see at work making the cell into a whole. It is a principle of wholeness which forms a unity from parts which would otherwise go their separate ways. Thus a hologenous system is born" (SchubertSoldern 1962:113). But what about the difference between animals and humans? 


\section{INSTINCTIVELY SECURED AND MILIEU-BOUND ANIMALS: THE ECCENTRIC HUMAN BEING IS OPEN TO THE WORLD}

Plessner holds that animals are closed and centric, thus distinguishing themselves from humans who are eccentric living beings. He then introduces the idea of Weltoffenheit (openness towards the world) (Plessner 1975:292; Plessner 1975a:378). Being open towards the world entails that there are no inaccessible boundaries between humans and their ambients. Yet, as we noted, acknowledging the absence or presence of boundaries clearly plays an important role in understanding the nature and difference between material entities and living entities. But living entities do not form an amorphous group, although biologists always struggled to provide a water-tight classification of plants and animals. ${ }^{4}$

What Portmann designates as the instinctively secured nature of animals ${ }^{5}$ surfaces in inherited behavioural action patterns and they are contrasted with the Weltoffenheit of humans (Portmann 1990:79). Being open to the world further explores the idea of open boundaries.

We investigate first of all what it means to be secured by instincts.

\section{EMOTIONAL BOUNDARIES: (NON- CONCEPTUAL) INBORN ACTIVATING MECHANISMS}

Particular stimuli or a combination of them may set in motion an action pattern that precedes any prior experience. It appears to be an inborn disposition. The American robin, a migrating songbird, known as Turdus migratorius (North American Robin), shows how a fake or dummy still triggers an inborn behavioural action pattern. In German it is designated as an inborn activating mechanism ("angeborene Auslösemechanismus" AAM) which does not need any conceptual understanding. In the case of the robin this inborn activating mechanism enables it to differentiate between what should and what should not pass through established emotional boundaries (the domain of the bird). The bright red-breasted robin controls its own

$4 \quad$ Alternatively up to five kingdoms have been proposed, demarcating Monera (bacteria, blue-green algae); Protista (protozoa, chrysophytes); Fungi (slime moulds, true fungi); Plantae (algae and higher plants); and Animalia (multicellular animals)" (see Bock, 1989:102). The current preference is to distinguish between Prokaryotes (without a nucleus) and Eukaryotes (with a nucleus). The former are mostly unicellular living entities without organelles with membranes as boundaries. Eukaryotes can be unicellular or multicellular and they may have a large number of sub-cellular organelles. In addition to the nucleus with its pores and nucleoles, other organelles found in the endoplasmic reticulum (either smooth or rough), are the endomembrane system, the Golgi apparatus (constituted by dictysome membranes), lysosomes, mitochondria, ribosomes, centrioles and peroxisomes. Classifying living entities in this way is dependent upon the presence or absence of boundaries.

5 Portmann appreciates Von Uexküll as the biologist who focused on the living subject in the centre of its Umwelt (Portmann 1970:XXIV). domain. Observing fellow species members triggers a specific protection-action-pattern in the robin with a bright red breast.

Any normal "trespasser" entering this domain will be attacked. Yet no conceptual bordering off (delineation) is present, for in 1943 Lack artificially constructed a substitute robin without a red breast and put it within the domain of a robin. No attack occurred! But the artificial construction of a robin with a red breast immediately once again activated the attack! The same result was reached in 1960 when Peiponen investigated the behaviour of blue-breast robins (Eibl-Eibesfeldt 2004:162-163).

What is absent in the behaviour of robins is the concept of a robin as a bird! For this reason it clearly differs from human perception which is capable of identifying a robin as a bird. Human perception is therefore cognitively opened up and deepened by means of conceptual representations and it allows for cognitively discerning conceptual boundaries.

\section{SUBJECT-ORIENTED UMWELT- SELECTION IN ANIMAL LIFE}

Before we focus on the demarcating role of human cognitive abilities another feature of animal life, related to boundaries, requires our attention. Although we may be inclined to think that animals depend upon their environment, animals in fact, as sentient subjects, actively select and construe their biomilieu (ambient / Umwelt). They accomplish this on the basis of the sensory subject-object relation. Von Bertalanffy mentions that the sole reaction of the paramecium as a unicellular organism is to flee (this flight reaction is known as phobotaxis and it occurs in reacting to "diverse chemical, tactile, thermal, photic" etc. stimuli). In the absence of any specific sense organs, this reaction is quite remarkable because it appears to be sufficient to guide this animal to live in optimal conditions. What is not related to this fleeing reaction is simply degraded to non-existence. Von Bertalanffy points out that the "many things in the environment of the paramecium," such as "algae, other infusoria, little crustaceans, mechanical obstacles and the like, are non-existent for it". One stimulus is sufficient to trigger the flight reaction (Von Bertalanffy, 1973:241). This example demonstrates that the organizational and functional plan of a living entity is decisive in selecting what can become a "stimulus" and a "characteristic" to which the organism will react in a specific way:

According to von Uexküll's view, any organism, so to speak, cuts out from the multiplicity of surrounding objects a small number of characteristics to which it reacts and whose ensemble forms its 'ambient' (Umwelt). All the rest is non-existent for that particular organism. Every animal is surrounded, as by a soap bubble, by its specific ambient, replenished by those characteristics which are amenable to it. If, when reconstructing an animal's ambience, we enter this soap bubble, the world is profoundly changed: Many characteristics disappear, others arise, and a completely new world is found (Von Bertalanffy 1973:241). 
The boundaries between the "soap bubble" and a given environment demonstrate the active role of the animal subject in this regard, even though a striking poverty of sensory abilities may prevail. Jakob von Uexküll illustrates this point with reference to the world of a tick. A tick reduces its environment in an astonishing way, for at the edge of a branch in the bushes it awaits motionlessly the event of a passing mammal. No other stimulus from the total environment is noticed. But when a mammal approaches the tick lets go. Von Bertalanffy explains:

Take, for instance, a tick lurking in the bushes for a passing mammal in whose skin it settles and drinks itself full of blood. The signal is the odour of the butyric acid, flowing from the dermal glands of all mammals. Following this stimulus, it plunges down; if it fell on a warm body - as monitored off by its sensitive thermal sense - it has reached its prey, a warm-blooded animal, and only needs to find, aided by tactile sense, a hair-free place to pierce in. Thus the rich environment of the tick shrinks to metamorphize into a scanty configuration out of which only three signals, beaconlike, are gleaming which, however, suffice to lead the animal surely to its goal (Von Bertalanffy 1973:241). ${ }^{6}$

\section{THE DISTINCTION BETWEEN AMBIENT AND ENVIRONMENT}

Von Uexküll remarks that the "ambient" ("Umwelt") and the "environment" (Umgebung) of an animal are not identical. What is remarkable is that of all the effects proceeding from the mammalian body, only three are turned into stimuli. From the grandiose world surrounding the tick these three stimuli serve as a guide for the tick to reach its goal with certainty. Its world encompasses only three characteristics and three actions (Merkmalen and Wirkmalen) (Jakob von Uexküll, 1970:12-13). Sea urchins may strike together their spines in reaction to the darkening caused by a cloud or by the danger of an approaching fish. Von Bertalnffy summarizes: "Thus, while the environment of the sea urchin contains many different objects, its ambient only contains one characteristic, namely, dimming of light" (Von Bertalanffy 1973:242). Moreover, as Thure von Uexküll points out, the ambients are not elements in an atomistic sense, for they are embedded within an encompassing "Planmäßigkeit" (Thure von Uexküll 1970:XXVI).

Clearly emotional boundaries simply differ from physical boundaries - a fact also illustrated by the difference between sensory and physical space.

\section{SENSORY SPACE AND PHYSICAL SPACE}

Similar to the above-mentioned distinction between physical space and mathematical space there is also a difference

$6 \quad$ Of course it may happen that the tick needs to wait for quite a time before a mammal passes. But it is equipped to cope with this obstacle, for ticks have been reported to subsist for 18 years without food (cf. Jakob von Uexküll 1970:13-14)! between sensory space and physical space. The human skin, for example, may experience separate pricks as continuous, even though they in fact are physically discontinuous (distinct) (see Gosztonyi, 1976, I:13). This demonstrates yet another (non-spatial) context within which the multivocality of spatial phenomena can be observed.

\section{DISCERNING THE BOUNDARIES BETWEEN DIFFERENT MODES OF EXPLANATION}

Human cognitive abilities can also be revealed, for example when analytical control or analytical mastery of a domain of knowledge takes place. This may occur when certain modes of being (modal aspects) are lifted out while others are disregarded. But lifting out and disregarding are nothing but what happens when abstraction takes place. Combining the nature of abstraction and the nature of modal aspects highlights the distinctive feature of scholarly thinking (including the natural sciences and the humanities), because it is typical of the special sciences to approach concrete reality through the gate-way of modal aspects which are then at once opened up to become modes of explanation. Through modal abstraction the functional boundaries between the various aspects of reality are brought to light. This observation only holds when these modes of explanation are irreducible, i.e. if we subscribe to a non-reductionist ontology.

\section{THE ROLE OF BOUNDARIES BETWEEN (UN-)DIFFERENTIATED SOCIETAL SPHERES}

Distinct societal entities within a differentiated society assign a unique focus to communal and collective human actions by combining alternative qualifying functions with analogies of the spatial notion of spheres or circles. Consider expressions such as cultural-historical spheres, lingual spheres, social spheres, legal spheres, and so on.

Traditional undifferentiated societies display one fixed ("closed") form of organization which does not allow for the free flow (interaction) between their members and those of other undifferentiated societies. The initial Roman ius civile, for example, was an exclusive undifferentiated folk law. Non-Romans did not have any rights since they were exlex, hostis (Mackenzie, 1898:77ff.). A long cultural-historical process of differentiation was needed before more people around the world were taken up in the cultural intercourse between the various nations who participated peacefully in these interactions. Every distinct societal entity within a differentiated society is both open and closed - analogous to thermodynamically open systems. Insofar as the office-bearers of societal communities and collectivities occupy their respective offices, it is presupposed that there are set limits or boundaries for the competencies of these officebearers. Of course these boundaries entail a normative calling which could be carried out in a better or worse way.

The designation of the borders or boundaries of specific societal forms of life always fall back on one or another spatial notion. It was Groen van Prinsterer, Abraham Kuyper and Herman 
Dooyeweerd who established the idea of sphere-sovereignty. More recent alternative characterizations of societal spheres continue to appeal to spatial terms, such as the inside-outside contrast. Münch speaks of the inner laws of societal entities, such as the state (Münch 1990:442, 444) Habermas uses the expression "own laws" ("Eigengesetzlichkeit" - Habermas 19952:437), while Rawls holds that elements of society need some "sphere" with its "own principles" fitting "their peculiar nature" because there are "different principles for distinct kinds of subjects" (Rawls 1996:262).

\section{PERSISTENCE AMIDST CHANGE: THE NATURE OF A SOLIDARY UNITARY CHARACTER}

Within a differentiated society the acknowledgement of distinct societal spheres with their typical boundaries does not preclude a free and open interaction between societal entities. One of the features of particular communal relationships and societal collectivities is that they display a solidary unitary character. This property entails that communities and collectivities maintain their societal identities in spite of the coming and going of their individual members over time. It represents an analogy of thermodynamic open systems, where, as we noted earlier, the relative endurance of a physical system or of living entities is observed from the perspective of their typical functioning within the physical aspect. It embodies the kinematic and physical analogies within the social aspect.

These kinematic and the physical analogies within the structure of the social aspect intends to capture the phenomenon that, in spite of the constant flow (coming and going, entering and leaving) of individual members of a societal collectivity, it still preserves the identity of the social form of life over time.

This property reflects the solidary unitary character of certain societal entities. Ryan stumbled upon this feature where he writes about "fluctuating membership":

There are regularities and constancies in the behavior of groups of people which allow us to talk about groups having a stable structure in spite of fluctuating membership, and about the existence of social roles which can be filled by different people at different points in time (Ryan 1980:174).

Similar to phenomena expressing themselves within the physical aspect, such as the open structure of certain thermodynamic processes, fluctuating membership therefore shows that analogies of thermodynamic open systems are also found within the social aspect, thus highlighting open boundaries within a differentiated society.

An interesting trait accompanies ecclesiastical law because it is attached to the person without obstructing physical boundaries between different congregations. Even if a church member leaves the boundaries of a congregation the authority over such a person is not suspended. This situation differs from what is the case in a constitutional state.

\section{STATE BOUNDARIES: OPEN AND LIMITED}

The modern idea of the state as a public legal institution rests on the basis of having the monopoly over state-power (the army against external threats and the police force for internally maintaining law and order) on its territory (a cultural area with set boundaries). Inter-state intercourse and the flow of tourists and migrants need open borders without generating a threat to the territorial integrity of a state.

\section{ACADEMIC BOUNDARIES BETWEEN DISCIPLINES: PHILOSOPHY INVESTIGATES BOUNDARY PROBLEMS}

Thus far we have briefly discussed multiple instances of nonspatial contexts in which the original (modal) spatial concept of a border acquires analogical meanings and we have highlighted the fact that these contexts require an appreciation from the perspective of a non-reductionist ontology. We conclude with a brief remark regarding the role of boundaries between academic disciplines and the significance of borders for philosophical reflection in general.

The horizon of experience of the world is constituted by mutually irreducible aspects, which at once may serve as ontic modes of explanation. When they serve the explanatory power of various academic disciplines their ontic status is presupposed. Owing to the inter-connections between the diverse aspects of reality, the selection of any aspect as angle of approach for the theoretical investigation of reality can never isolate itself from all the other modes of explanation. Just recall the coherence between the spatial and physical aspects where it appeared that the meaning of the physical aspect, among others, comes to expression in its coherence with the spatial aspect, evinced in the difference between mathematical space and physical space [although both are extended (the similarity between them) the former is continuous and infinitely divisible and the latter is neither continuous nor infinitely divisible].

It belongs to the task of philosophy to investigate the demarcation of the various entities and aspects of reality. In itself this task leads to an account of the various academic disciplines that employ the gate-way of these aspects to investigate reality.

One may here refer to the boundary problems with which philosophy continues to wrestle. Van Riessen even suggested that we should see philosophy as the discipline involved in analysing boundary questions ("grensvragen" - Van Riessen 1970:11, 19, 20).

\section{CONCLUDING REMARK}

Although the nature of boundaries primarily directed our attention to space, we subsequently used multiple examples to argue that the awareness of boundaries forms an integral part of our experience of the universe. But a proper understanding of boundaries does require a refined analysis of apparently widely 
diverging phenomena, one in which both the uniqueness and unbreakable coherence between its various manifestations are accounted for. Without an implicit or explicit knowledge of them, human life will disintegrate and become directionless, and only a non-reductionist ontology can safeguard us against one-sided -ismic orientations which aim at reducing the rich diversity of aspects and (natural and social) entities to one or another reified perspective, such as is known to us in physicalism, vitalism, psychologism, logicism, historicism, materialism, aestheticism, legalism, moralism or pietism.

What has not been done in the present article is to account for the kind of knowledge surfacing when we approximate what lies beyond the grasp of normal concept formation. For example, it belongs to the classical legacy in epistemology to note that since concept formation is directed towards what is universal, conceptual knowledge is blind towards what is individual (de singularibus non est scientia = of what is singular no science is possible). Yet we still have knowledge of what is unique and individual. This opens the way towards a reflection on the nature of concept-transcending knowledge - exceeding the scope of this article.

\section{LITERATURE}

ALEXANDER, J.C. 1990. Differentiation Theory and Social Change. Co-editor Paul Colomy, New York: Columbia University Press.

ARISTOTLE, 2001. The Basic Works of Aristotle. Edited by Richard McKeon with an Introduction by C.D.C. Reeve. (Originally published by Random House in 1941). New York: The Modern Library.

BELL, J.L. 2006. The continuous and the infinitesimal in mathematics and philosophy. Corso Milano: Polimetrica.

BERNAYS, P. 1976. Abhandlungen zur Philosophie der Mathematik. Darmstadt: Wissenschaftliche Buchgesellschaft.

BOCK, W.J. 1989. Animal kingdom. (In McGraw-Hill, 1989. Concise Encyclopedia of Science \& Technology. New York: McGraw-Hill Publishing Company.)

BÖHME, G. 1966. Unendlichkeit und Kontinuität. Philosophia Naturalis. Volume II, (pages 304-317).

CANTOR, G. 1895. Beiträge zur Begründung der transfiniten Mengenlehre. (In Mathematische Annalen, Volume 46:481-512.

DRIESCH, H. 1921. Philosophie des Organischen, Leipzig: Engelmann.

EIBL-EIBESFELDT, I. 2004. Grundriß der vergleichenden Verhaltensforschung, Ethologie. $8^{\text {th }}$ revised edition. Vierkirchen-Pasenbach: Buch Vertrieb Blank GmbH.

FREGE, G. 1979. Posthumous writings. Oxford: Basil Blackwell.

GOSZTONYI, A. 1976. Der Raum; Geschichte seiner Probleme in Philosophie und Wissenschaften. Freiburg: Alber (Vols.1\& 2).

HABERMAS, J. 1995-1 \& 1995-2. Theorie des kommunikativen Handelns. [Theory of Communicative Action] Volume 1 \& Volume 2. Frankfurt am Main: Suhrkamp Verlag (Fourth revised Edition, 1987 - 'Taschenbuch' Edition 1995 - originally published in 1981).

HEITLER, W. 1976. Ueber die Komplementarität von Lebloser und lebender Materie, Abhandlungen der mathematisch-naturwissenschaftlichen Klasse, Jahrgang 1976, No.1, Mainz (Monograph).

HILBERT, D. 1925. Ueber das Unendliche. Mathematische Annalen, 95:161-190.

LAUGWITZ, D. 1986. Zahlen und Kontinuum. Eine Einführung in die Infinitesimalmathematik. Mannheim: B.I.-Wissenschaftsverlag.

LONGO, G. 2001. The Mathematical Continuum: From Intuition to Logic. ftp://ftp.di.ens.fr/pub/users/longo/PhilosophyAndCognition/the-continuum. pdf (accessed on October 19, 2010).

MACKENZIE, Lord 1898. Studies in Roman Law with comparative views of the laws of France, England and Scotland. $7^{\text {th }}$ ed., edited by J. Kirkpatrick. Edinburgh: William Blackwood \& Sons.

MADDY, P. 2005. Three forms of naturalism. In: Shapiro, 2005:437-459. [SHAPIRO, S. 2005 (Editor). The Oxford Handbook of Philosophy of Mathematics and Logic. Oxford: Oxford University Press.]

MADDY, P. 2005. Three forms of naturalism. In: Shapiro, 2005:437-459. [SHAPIRO, S. 2005 (Editor). The Oxford Handbook of Philosophy of Mathematics and Logic. Oxford: Oxford University Press.]

MÜNCH, R. 1990. Differentiation, Rationalization, Interpenetration: The Emergence of Modern Society, in: Alexander, 1990a (pages 441-464). [ALEXANDER, J.C. 1990. Differentiation Theory and Social Change. Co-editor Paul Colomy, New York: Columbia University Press.]

PLESSNER, H. 1965². Die Stufen des Organischen und der Mensch, Einleitung in die philosophische Antropologie. Berlin: Walter de Gruyter. 
PLESSNER, H. 1975. Autobiographical Chapter: Helmut Plessner. In: Pongratz 1975 (pp.269-307). Add details

PLESSNER, H. 1975a. Zur Anthropologie der Sprache. In: Philosophia Naturalis, Vol.15, Section 4:375-381.

PONGRATZ, L.J. 1975. Philosophie in Selbstdarstellungen, Hamburg: Felix Meiner.

PORTMANN, A. 1970. Ein Wegbereiter der neuen Biologie, Vorwort. In: Jakob von Uexküll 1970 (pages IX-XXI). [VON UEXKÜLL, J. \& KRISZAT, G. 1970. Streifzüge durch die Umwelten von Tieren und Menschen, Bedeutungslehre. Frankfurt am Main: S. Fischer Verlag.]

PORTMANN, A. 1990. A zoologist looks at humankind. New York: Columbia University Press.

RAWLS, J. 1996. Political Liberalism. Revised Edition. Cambridge: Harvard University Press.

RYAN, A. 1980. The philosophy of the social sciences. London: Macmillan.

SCHRÖDINGER, E. 1955. What is Life? The Physical Aspect of the Living Cell, Cambridge: University Press.

SCHUBERT-SOLDERN, R. 1962. Mechanism and Vitalism. London: Burns \& Oates.

SHAPIRO, S. 2005 (Editor). The Oxford Handbook of Philosophy of Mathematics and Logic. Oxford: Oxford University Press.

TRINCHER, K. 1985. Die Dualität der Materie. Philosophia Naturalis, 22(3):329-342).

VAN RIESSEN, H. 1970. Wijsbegeerte. Kampen: Kok N.V.

VON BERTALANFFY, L. 1973. General System Theory. Hammondsworth: Penguin University Books.

VON UEXKÜLL, J. \& KRISZAT, G. 1970. Streifzüge durch die Umwelten von Tieren und Menschen, Bedeutungslehre. Frankfurt am Main: S. Fischer Verlag.

VON UEXKÜLL, J. 1973. Theoretische Biologie (1928). Berlin: Springer.

VON UEXKÜLL, Th. 1970. Die Umweltforschung als subjekt- und objektumgreifende Naturforschung. In: Uexküll, Jakob von, 1970 (pp.XXIII-XLVII).

WEYL, H. 1921. Ueber die neue Grundlagenkrise der Mathematik. Mathematische Zeitschrift, 10:39-79.

YOURGRAU, P. 2005. A world without time. The forgotten legacy of Gödel and Einstein. London: Penguin Books. 